Marchand, P.J. 1984. Sapwood area as an estimation of foliage biomass and projected leaf area for Abies balsamea and Picea rubens. Can. J. For. Res. 14: 85-87.

Nelson, H.D. 1976. Gross influence on heartwood formation in black walnut and black cherry trees. USDA For. Res. Pap. FLP 268.

Smith, J.H.G., J. Walters \& R.W. Wellwood. 1966. Variation in sapwood thickness of Douglas-fir in relation to tree and section characteristics. For. Sci. 12: $97-$ 103.

Todorovsky, S. 1966. Effect of certain factors on the proportion of sapwood and heartwood in the stem of Pinus sylvestris and Pinus nigra. Summary from For. Abstr. 1968. No. 2908.

Trendelenburg, R. 1939. Das Holz als Rohstoff. J.F. Lehmann Verlag, München.
Wellwood, R.W. 1955. Sapwood-heartwood relationships in second-growth Douglasfir. For. Prod. J. 5: 108-111.

Wellwood, R.W. \& P.E. Jurazs. 1968. Variation in sapwood thickness, specific gravity and tracheid length in western red cedar. For. Prod. J. 18: 37-46.

Yang, K.C. \& G. Hazenberg. 1991a. Sapwood/heartwood width relationship to tree age in Pinus banksiana Lamb. Can. J. For. Res. (In press).

Yang, K.C. \& G. Hazenberg. 1991b. Relationship between tree age and sapwood/ heartwood width in Populus tremuloides Michx. Wood and Fibre Science. (In press).

Yang, K.C., G. Hazenberg, G.E. Bradfield \& J.R. Maze. 1985. Vertical variation of sapwood thickness in Pinus banksiana Lamb. and Larix laricina (Du Roi) K. Koch. Can. J. For. Res. 15: 822-828.

\title{
Index Xylariorum 3 - Addendum
}

SUCURSAL: Museo Argentino de Ciencias Naturales 'B. Rivadavia' e Instituto Nacional de Investigación de las Ciencias Naturales, (BAw), Avda. Angel Gallardo 470, Casilla de Correo 220, Sucursal 5, 1405 Buenos Aires, Argentina.

Foundation: 1947.

Curator: Prof. CARLOS ALEJANDRO NOVERTO (Comparative anatomy of angiosperms, especially wood anatomy).

Collection: 940 specimens; 220 genera.

Specialisation: Argentina, Paraguay.

Herbarium vouchers: Yes; about 100,000; 92 per cent of wood specimens vouchered.

Periodical or serial publications: Revista de Museo Argentino de Ciencias Naturales 'B. Rivadavia' e Instituto Nacional de Investigación de las Ciencias Naturales.

Samples for sectioning: Yes.

Microscope slides: Yes.

Exchange: Yes. Wanted: Woods from Argentina and Paraguay, especially material from shrubs and climbers.

Remarks: A catalogue of the wood collection is available on request from the curator. 